\title{
Ellagic acid inhibits lipopolysaccharide-induced expression of enzymes involved in the synthesis of prostaglandin $E_{2}$ in human monocytes
}

\author{
Sofia Karlsson, Eewa Nånberg, Christina Fjaeraa and Jonny Wijkander* \\ Department of Chemistry and Biomedical Sciences, Karlstad University, SE-651 88 Karlstad, Sweden
}

(Received 30 May 2009 - Revised 21 August 2009 - Accepted 8 September 2009 - First published online 1 December 2009)

Ellagic acid, a natural polyphenol found in certain fruits, nuts and vegetables, has in recent years been the subject of intense research within the

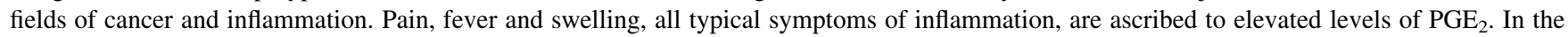
present study, we have investigated the effects of ellagic acid on $\mathrm{PGE}_{2}$ release and on prostaglandin-synthesising enzymes in human monocytes. Ellagic acid was found to inhibit Ca ionophore A23187-, phorbol myristate acetate- and opsonised zymosan-induced release of PGE 2 from monocytes pre-treated with the inflammatory agent lipopolysaccharide. Ellagic acid suppressed the lipopolysaccharide-induced increase in protein expression of cyclo-oxygenase-2 (COX-2), microsomal PGE synthase-1 (mPGEs-1) and cytosolic phospholipase $\mathrm{A}_{2} \alpha$ (cPLA $\mathrm{A}_{2} \alpha$ ), while it had no effect on the constitutively expressed COX-1 protein. Ellagic acid had no apparent inhibitory effect on these enzymes when the activities were determined in cell-free assays. We conclude that the inhibitory effect of ellagic acid on $\mathrm{PGE}_{2}$ release from monocytes is due to a suppressed expression of COX-2, mPGEs- 1 and $\mathrm{cPLA}_{2} \alpha$, rather than a direct effect on the activities of these enzymes.

Ellagic acid: Prostaglandin $\mathrm{E}_{2}$ : Human monocytes

$\mathrm{PGE}_{2}$, which belongs to the family of eicosanoids, is a potent lipid mediator that is produced in most cell types. During inflammation, increased levels of $\mathrm{PGE}_{2}$ are seen in response to various substances such as cytokines, growth factors and bacterial agents ${ }^{(1)}$. The production of $\mathrm{PGE}_{2}$ is dependent upon the activity of several enzymes involved in the arachidonic acid (AA) cascade. AA is liberated from cellular membrane phospholipids through the action of different types of phospholipase $\mathrm{A}_{2}\left(\mathrm{PLA}_{2}\right)$. This family of enzymes can be divided into three main groups: secretory $\mathrm{PLA}_{2}, \mathrm{Ca}$-independent $\mathrm{PLA}_{2}$ and cytosolic $\mathrm{PLA}_{2}{ }^{(2,3)}$. Among these, the ubiquitously expressed cytosolic $\mathrm{PLA}_{2} \alpha\left(\mathrm{cPLA}_{2} \alpha\right)$ has gained interest in eicosanoid production due to its preferential hydrolysis of AA-containing phospholipids and its activation in response to various inflammatory stimuli ${ }^{(4,5)}$. Following mobilisation, $\mathrm{AA}$ is subsequently converted by either the constitutively expressed cyclo-oxygenase-1 (COX-1) or the inducible COX-2 to the intermediate $\mathrm{PGH}_{2}$, which is then further metabolised to various prostaglandins. Among these, $\mathrm{PGE}_{2}$ is the main prostaglandin released from lipopolysaccharide (LPS)-treated monocytes ${ }^{(6)}$. $\mathrm{PGH}_{2}$ is converted to $\mathrm{PGE}_{2}$ by one of three different isoforms of PGE synthase (PGEs): cytosolic PGEs (cPGEs) and microsomal PGEs 1 and 2 (mPGEs-1, mPGEs-2 $)^{(7)}$. cPGEs and mPGEs-2 are in most cell types regarded as constitutively expressed proteins while mPGEs-1, along with $\mathrm{COX}-2$, are known to be inducible ${ }^{(8)}$. COX-2 and mPGEs-1 are also considered to be the main actors when $\mathrm{PGE}_{2}$ is produced during inflammation ${ }^{(9)}$.
Ellagic acid is a polyphenolic compound of which the highest levels are found in fruits such as pomegranate, blackberries, raspberries and strawberries. Juices from these fruits have been proposed to have health-beneficial properties. Ellagic acid has been shown to inhibit proliferation and to initiate apoptosis in certain forms of cancer cell lines ${ }^{(10-14)}$ as well as having anti-inflammatory effects ${ }^{(15,16)}$. The molecular mechanisms by which ellagic acid exerts its effects are largely unknown, although ellagic acid has been shown to affect protein kinases, such as mitogen-activated protein kinases $^{(17,18)}$ and also to modulate the activity of transcription factors, such as $\mathrm{NF}_{\kappa} \mathrm{B}^{(16,19,20)}$. As a consequence of the reported positive effects from a health point of view, a more intense research concerning the exact mechanisms by which ellagic acid exerts its effects is in demand.

In the present study we have investigated the effects of ellagic acid on $\mathrm{PGE}_{2}$ release and on expression of the enzymes involved in the synthesis of $\mathrm{PGE}_{2}$ in human monocytes.

\section{Materials and methods}

Materials

Buffy coats were obtained from the division of Clinical Immunology and Transfusion Medicine, Uppsala University Hospital (Uppsala, Sweden). Ficoll-Paque ${ }^{\mathrm{TM}}$ PLUS and 1-stearoyl$2\left[{ }^{14} \mathrm{C}\right]$ arachidonoyl-phosphatidylcholine were purchased from GE Healthcare (Little Chalfont, Bucks, UK). Dulbecco's

Abbreviations: AA, arachidonic acid; COX, cyclo-oxygenase; cPGEs, cytosolic PGE synthase; cPLA $2 \alpha$, cytosolic phospholipase $\mathrm{A}_{2} \alpha$; LPS, lipopolysaccharide; mPGEs, microsomal PGE synthase; PGEs, PGE synthase; PLA 2 , phospholipase $\mathrm{A}_{2}$; PMA, phorbol myristate acetate; TBS, Tris-buffered saline.

* Corresponding author: Dr Jonny Wijkander, fax +46 54700 1457, email jonny.wijkander@kau.se 
Modified Eagle Medium: Nutrient Mixture F-12 (DMEM:F12), penicillin and streptomycin and NuPAGE gels were obtained from Invitrogen (Carlsbad, CA, USA). Cellstar ${ }^{\circledR}$ twelve-well culture plates were purchased from Greiner Bio-One (Frickenhausen, Germany) and BD Falcon ${ }^{\mathrm{TM}} 100 \mathrm{~mm}$ cellculture plates from Becton Dickinson (Franklin Lakes, NJ, USA). Ellagic acid, LPS (Escherichia coli serotype 055:B5), A23187, Zymosan A, phorbol myristate acetate (PMA) and propidium iodide were all purchased from Sigma-Aldrich (St Louis, MO, USA). Pyrrophenone was generously provided by Dr Kauro Seno (Shianogi \& Co. Ltd, Osaka, Japan). Indomethacin, $\mathrm{NS} 398, \mathrm{PGH}_{2}$ and $\mathrm{AA}$, as well as a $\mathrm{PGE}_{2}$ enzyme immunoassay kit, were purchased from Cayman Chemicals (Ann Arbor, MI, USA). Primary antibodies (goat monoclonal anti-COX-2, goat monoclonal anti-COX-1, goat monoclonal anti-cPLA ${ }_{2} \alpha$ and rabbit monoclonal antimPGES-1), as well as peroxidase-conjugated donkey anti-goat and donkey anti-rabbit IgG were purchased from Santa Cruz Biotechnology (Santa Cruz, CA, USA). The Supersignal West Pico Chemiluminescent system was obtained from Thermo Fisher Scientific (Rochester, NY, USA).

\section{Isolation of monocytes}

Fresh human monocytes were isolated from buffy coats of healthy blood donors. The buffy coat was diluted with an equal volume of PBS containing $3 \mathrm{~mm}$-EDTA, and was then carefully loaded on Ficoll-Paque ${ }^{\text {TM }}$ PLUS and centrifuged at $800 \mathrm{~g}$ for $30 \mathrm{~min}$ at $20^{\circ} \mathrm{C}$. The separated mononuclear fraction was collected and diluted with PBS containing 3 mM-EDTA followed by centrifugation at $500 \mathrm{~g}$ for $15 \mathrm{~min}$. The pelleted cells were re-suspended in PBS containing 3 mM-EDTA and washed five times by centrifugation at $180 \mathrm{~g}$ for $10 \mathrm{~min}$. After washing, the cells were re-suspended in Dulbecco's Modified Eagle Medium: Nutrient Mixture F-12 (DMEM:F12; Invitrogen) culture medium supplemented with penicillin $(100 \mathrm{U} / \mathrm{ml})$, streptomycin $(100 \mu \mathrm{g} / \mathrm{ml})$ and $5 \%(\mathrm{v} / \mathrm{v})$ human serum. The cells were seeded onto polystyrene cell-culture plates and allowed to adhere for $2 \mathrm{~h}$. Non-adherent cells were washed away with PBS containing $1 \mathrm{mM}^{-\mathrm{CaCl}_{2}}$ and $1 \mathrm{mM}-$ $\mathrm{MgCl}_{2}$, and fresh serum-free medium was added. The cells were maintained at $37^{\circ} \mathrm{C}$ in a humidified atmosphere of $5 \%$ $\mathrm{CO}_{2}$ for a total time of $2 \mathrm{~d}$.

\section{Pre-treatment of monocytes}

After $1 \mathrm{~d}$ in culture, the monocytes were washed three times with PBS containing $1 \mathrm{~mm}-\mathrm{CaCl}_{2}$ and $1 \mathrm{mM}-\mathrm{MgCl}_{2}$ and fresh medium was added. Cells were either left untreated (control) or pre-treated with LPS $(1 \mu \mathrm{g} / \mathrm{ml})$ for $20 \mathrm{~h}$ with or without combined pre-treatment with various concentrations of ellagic acid. Freshly made ellagic acid, dissolved in dimethyl sulfoxide to a concentration of $10 \mathrm{~mm}$, was added to the cells $1 \mathrm{~h}$ before LPS. An equal volume of dimethyl sulfoxide, with no ellagic acid, added to control cultures had no effect on any of the experimental read-outs measured in the present study. Cell viability was determined by propidium iodide staining (incubation of cells with $50 \mu \mathrm{g} / \mathrm{ml}$ for $15 \mathrm{~min}$ ) and counting of stained cells using a fluorescence microscope with $545 \mathrm{~nm}$ excitation and $605 \mathrm{~nm}$ emission filters.

\section{Immunoblotting}

The cells (approximately $8 \times 10^{6}$ cells) were scraped in $150 \mu \mathrm{l}$ Laemmli sample buffer ${ }^{(21)}$ containing leupeptin $(1 \mu \mathrm{g} / \mathrm{ml})$, aprotinin $(1 \mu \mathrm{g} / \mathrm{ml}), 1 \mathrm{mM}$-phenylmethylsulfonyl fluoride and $5 \%(\mathrm{v} / \mathrm{v}) \beta$-mercaptoethanol and boiled for $5 \mathrm{~min}$. A quantity of $25 \mu$ l of lysates was loaded to NuPAGE 2-amino2-hydroxymethyl-propane-1,3-diol (Tris) glycine gradient gel $(4-12 \%)$ and separated proteins were electrotransferred onto polyvinylidene difluoride membranes. The membranes were blocked with $2.5 \%(\mathrm{v} / \mathrm{w})$ gelatine in Tris-buffered saline (TBS) containing $0.1 \%(\mathrm{v} / \mathrm{v})$ Tween-20 for $1 \mathrm{~h}$ at room temperature, washed two times in TBS-Tween-20 and incubated overnight at $8^{\circ} \mathrm{C}$ with primary antibodies: goat monoclonal anti-cPLA ${ }_{2} \alpha$ (1:500), goat monoclonal anti-COX-2 (1:300), goat monoclonal anti-COX-1 (1:300) or rabbit monoclonal anti-mPGEs-1 (1:250). The membranes were washed five times for $10 \mathrm{~min}$ in TBS-Tween-20 and thereafter incubated for $1 \mathrm{~h}$ with the appropriate horseradish peroxidase-conjugated secondary antibodies: donkey anti-goat $\operatorname{IgG}(1: 4000)$ for $\mathrm{cPLA}_{2} \alpha, \mathrm{COX}-1$ and COX-2 and donkey anti-rabbit IgG $(1: 1500)$ for mPGEs-1. The membranes were washed five times with TBS-Tween-20 and proteins were detected with the Supersignal West Pico Chemiluminescent system and captured on X-ray film. Films were scanned and band intensity was analysed using ImageQuant TL (GE Healthcare). The relative band intensities of $\mathrm{cPLA}_{2} \alpha, \mathrm{COX}-2$ and mPGEs- 1 were normalised to the corresponding band of the constitutively expressed COX-1.

\section{Analysis of $P G E_{2}$ release from intact monocytes}

For analysis of $\mathrm{PGE}_{2}$ release, monocytes were cultured on twelve-well plates (approximately $0.5 \times 10^{6}$ cells per well). After pre-treatment for $20 \mathrm{~h}$ with LPS, with or without ellagic acid, the cells were washed three times and fresh medium was added to the wells. The cells were then allowed to equilibrate for $30 \mathrm{~min}$ before medium once more was exchanged with $1 \mathrm{ml}$ pre-warmed $\left(37^{\circ} \mathrm{C}\right)$ medium. Cells were stimulated with $0.5 \mu \mathrm{M}-\mathrm{A} 23187,150 \mathrm{nM}-\mathrm{PMA}$ or opsonised zymosan $(0.5 \mathrm{mg} / \mathrm{ml})$ for 30,45 and $60 \mathrm{~min}$ respectively. Culture medium from each well was transferred into collecting tubes and centrifuged at $3000 \mathrm{rpm}$ for $2 \mathrm{~min}$. The amount of released $\mathrm{PGE}_{2}$ was determined with a monoclonal $\mathrm{PGE}_{2}$ enzyme immunoassay kit according to the manufacturer's instructions. Results, pg released $\mathrm{PGE}_{2}$ per $\mathrm{ml}$ medium, are expressed as percentage of maximum release for each stimuli and standard errors.

\section{Isolation of subcellular fractions}

Monocytes for preparation of subcellular fractions were cultured on $100 \mathrm{~mm}$ cell-culture plates (approximately $8 \times 10^{6}$ cells per plate) and treated as described above. After washing the plates three times with PBS, cells from three culture plates were scraped off in a total volume of $1 \mathrm{ml}$ ice-cold Buffer X (80 mM-KCl, 1 mM-EDTA, 10 mM-HEPES, pH 7.4) containing leupeptin $(1 \mu \mathrm{g} / \mathrm{ml})$, aprotinin $(1 \mu \mathrm{g} / \mathrm{ml})$ and $1 \mathrm{mM}$-phenylmethylsulfonyl fluoride. The cell suspensions were sonicated with a probe sonicator for $2 \times 5 \mathrm{~s}$ at $4^{\circ} \mathrm{C}$ and centrifuged at $1700 \mathrm{~g}$ for $10 \mathrm{~min}$ at $4^{\circ} \mathrm{C}$. Supernatant fractions were 
transferred into centrifugation tubes and centrifuged at $60000 \mathrm{~g}$ for $90 \mathrm{~min}$ at $4^{\circ} \mathrm{C}$. The supernatant fractions (cytosolic fractions) were collected and glycerol was added to a final concentration of $10 \%(\mathrm{v} / \mathrm{v})$ and stored at $4{ }^{\circ} \mathrm{C}$ until assayed for $\mathrm{cPLA}_{2} \alpha$ activity. The pellets (microsomal fractions) were re-suspended in $500 \mu \mathrm{l}$ Buffer $\mathrm{X}$ containing leupeptin $(1 \mu \mathrm{g} / \mathrm{ml})$, aprotinin $(1 \mu \mathrm{g} / \mathrm{ml})$ and $1 \mathrm{mM}$-phenylmethylsulfonyl fluoride and sonicated $2 \times 5 \mathrm{~s}$ at $4^{\circ} \mathrm{C}$. Microsomal fractions were stored at $-20^{\circ} \mathrm{C}$ until assayed for mPGEs activity. The total amount of protein in each subcellular fraction was determined by the method of Bradford $^{(22)}$ using bovine serum albumin as standard.

\section{Assay of combined cyclo-oxygenase and PGE synthase activity}

A quantity of $15 \mu$ l of supernatant fractions from $1700 \mathrm{~g}$ centrifugation was mixed with Buffer $X$ containing $2 \mathrm{~mm}$ glutathione in a total volume of $100 \mu \mathrm{l}$. In experiments where the direct effect of ellagic acid on enzyme activity was determined, ellagic acid was added to the reaction mixtures and pre-incubated for $15 \mathrm{~min}$. Reactions were started by the addition of $0.5 \mu \mathrm{M}-\mathrm{AA}$, dissolved in ethanol. After $30 \mathrm{~min}$ incubation at $37^{\circ} \mathrm{C}$, the reactions were terminated by the addition of $400 \mu \mathrm{l}$ of ice-cold methanol and centrifuged at $10000 \mathrm{~g}$ for $10 \mathrm{~min}$ at $4^{\circ} \mathrm{C}$. Supernatant fractions were transferred into new collection tubes and dried under $\mathrm{N}_{2}$ gas, re-dissolved in culture medium and assayed for $\mathrm{PGE}_{2}$ with an enzyme immunoassay kit. The activity detected with this assay was inhibited by 100 (SEM 0) \% and 86 (SEM 6) \% (n 3) with $10 \mu \mathrm{M}$-indomethacin and $20 \mu \mathrm{M}-\mathrm{NS} 398$, respectively. Results are expressed as pg $\mathrm{PGE}_{2}$ per $\mu \mathrm{g}$ protein and standard errors.

\section{Assay of microsomal PGE synthase activity}

A quantity of $70 \mu \mathrm{l}$ of microsomal fractions was mixed with $30 \mu \mathrm{l}$ Buffer $\mathrm{X}$ containing $2 \mathrm{mM}$-glutathione and $10 \mu \mathrm{M}$ indomethacin. The mixtures were incubated for $15 \mathrm{~min}$, with or without the addition of ellagic acid, before the reaction was initiated by the addition of $0.5 \mu \mathrm{g}$ of $\mathrm{PGH}_{2}$ dissolved in ethanol. The enzyme reaction was allowed to proceed for $60 \mathrm{~s}$ at room temperature and was terminated by the addition of $25 \mu \mathrm{l} 100 \mathrm{~mm}-\mathrm{FeSO}_{4}$. Appropriate dilutions in culture medium were made for each reaction and assayed for produced $\mathrm{PGE}_{2}$ using an enzyme immunoassay kit. One reaction was assayed without enzyme source and considered as a control of non-enzymic conversion of $\mathrm{PGH}_{2}$ and this value was subtracted. Results are expressed as pg $\mathrm{PGE}_{2}$ per $\mu \mathrm{g}$ protein and standard errors.

\section{Assay of cytosolic phospholipase $A_{2} \alpha$ activity}

A quantity of $50 \mu \mathrm{l}$ of cytosolic fractions was assayed with sonicated vesicles of 1-stearoyl-2[ $\left.{ }^{14} \mathrm{C}\right]$ arachidonoyl-phosphatidylcholine $(100 \mathrm{pmol})$ as substrate and $1 \mathrm{mM}$-free $\mathrm{Ca}^{2+}$ in a total volume of $525 \mu \mathrm{l}$ of Buffer X. In experiments where the direct effect of ellagic acid on $\mathrm{cPLA}_{2} \alpha$ activity was investigated, ellagic acid was added to the reaction mixtures and pre-incubated for $15 \mathrm{~min}$. Incubations were terminated after $30 \mathrm{~min}$ at $37^{\circ} \mathrm{C}$ by the addition of $2 \mathrm{ml}$ chloroformmethanol-10 $\mathrm{M}-\mathrm{HCl}(2: 1: 0 \cdot 01$, by vol. $)$ and by the addition of carrier lipids (unlabelled AA and phosphatidylcholine). After centrifugation at $3000 \mathrm{rpm}$ for $10 \mathrm{~min}$, the lipid phase was subjected to silicic acid $(200 \mathrm{mg})$ column chromatography. Fatty acids were eluted with chloroform $(2 \times 0.5 \mathrm{ml})$ and phospholipids with methanol $(3 \times 1 \mathrm{ml})$ and radioactivity determined by scintillation counting. The activity detected with this assay was inhibited by 92 (SEM 6) \% ( $n$ 5) with $1 \mu \mathrm{M}$-pyrrophenone, a selective inhibitor of $\mathrm{cPLA}_{2} \alpha^{(23)}$. Results are expressed as pmol hydrolysed substrate per $\mu \mathrm{g}$ protein and standard errors.

\section{Statistical analysis}

Statistical analysis was performed using Student's paired two-sided $t$ test. $P<0.05$ was considered significant.

\section{Results}

Effect of ellagic acid on $P G E_{2}$ release in human monocytes

Human monocytes, pre-treated with LPS $(1 \mu \mathrm{g} / \mathrm{ml})$ for $20 \mathrm{~h}$, responded to a subsequent stimulation with either A23187, PMA or opsonised zymosan with a considerable release of $\mathrm{PGE}_{2}$ that amounted to $2 \cdot 5-3.5 \mathrm{ng} / \mathrm{ml}$. This $\mathrm{PGE}_{2}$ release is about 100-fold higher than that seen without LPS pretreatment in response to the same stimuli (results not shown). $\mathrm{PGE}_{2}$ release was also seen in response to LPS alone; however, this release was low $(0 \cdot 1$ (SEM $0 \cdot 04) \mathrm{ng} / \mathrm{ml}$ (n 5)) and subsequent experiments were therefore performed using the experimental set-up with LPS pre-treatment followed by stimulation with A23187, PMA or opsonised zymosan. Ellagic acid, added $1 \mathrm{~h}$ before pre-treatment with LPS, inhibited the $\mathrm{PGE}_{2}$ release induced by A23187, opsonised zymosan or PMA with a half maximal inhibition at $10-15 \mu \mathrm{M}$-ellagic acid (Fig. 1). Ellagic acid at $30 \mu \mathrm{M}$ inhibited the release seen with A23187, opsonised zymosan and PMA with 86.2 (SEM 5.3) \% ( $n$ 6), 92.7 (SEM 1.8) \% $(n$ 6) and 83.9 (SEM 3.6) \% ( $n$ 4), respectively. In contrast to the inhibition seen when ellagic acid was added before LPS pre-treatment, no inhibition of $\mathrm{PGE}_{2}$ release was seen when ellagic acid was added $15 \mathrm{~min}$ before stimulation with A23187, opsonised zymosan or PMA (results not shown).

Ellagic acid, at concentrations up to $20 \mu \mathrm{M}$, had no effect on cell viability as determined by propidium iodide staining, while $30 \mu \mathrm{M}$ revealed a $4.8(\operatorname{SEM} 3 \cdot 1) \%(n 4)$ and $50 \mu \mathrm{M}-$ ellagic acid more than $10 \%$ loss in cell viability.

\section{Effect of ellagic acid on the lipopolysaccharide-induced protein expression of prostaglandin-synthesising enzymes}

Next, we investigated if the effect of ellagic acid on $\mathrm{PGE}_{2}$ release was due to an impact on protein expression of the involved prostaglandin-synthesising enzymes: COX-1, COX-2, mPGEs-1 and $\mathrm{cPLA}_{2} \alpha$. Whole cell lysates, from resting monocytes as well as monocytes treated with LPS, with or without various concentrations of ellagic acid, were subjected to electrophoresis and immunoblotting. COX-1 protein was present in control cells and was not affected by LPS treatment or any used dose of ellagic acid (Fig. 2(a)). COX-2 protein was not detected in control cells, but, was markedly induced by LPS treatment (Fig. 2(b)). 


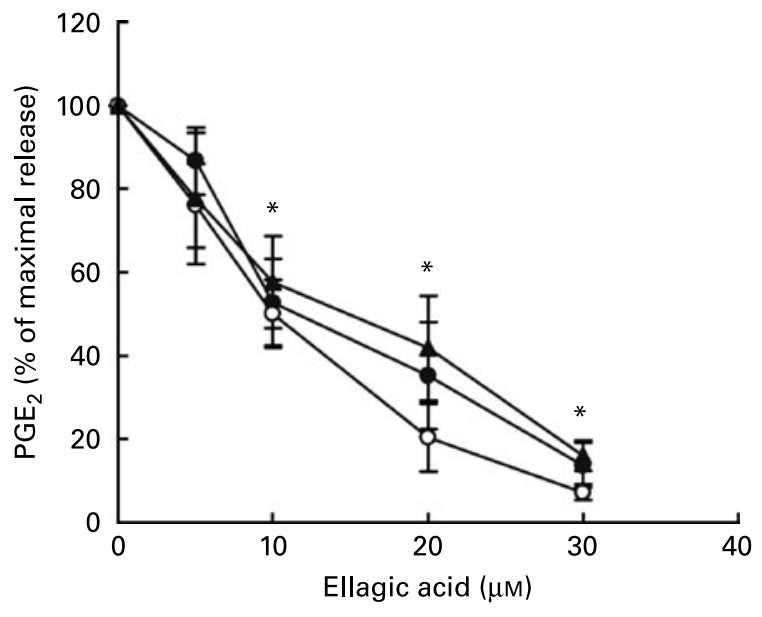

Fig. 1. Dose-dependent inhibitory effect of ellagic acid on $\mathrm{PGE}_{2}$ release from monocytes. Cells were pre-treated with lipopolysaccharide (LPS; $1 \mu \mathrm{g} / \mathrm{ml}$ ) for $20 \mathrm{~h}$ with or without indicated concentrations of ellagic acid (ellagic acid was added $1 \mathrm{~h}$ before LPS). Cells were washed and given fresh medium followed by stimulation with either $0.5 \mu \mathrm{M}-\mathrm{A} 23187(\bullet)$, opsonised zymosan

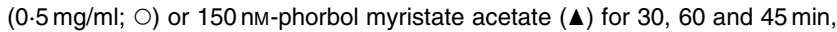
respectively. The culture medium was analysed for $\mathrm{PGE}_{2}$ release by enzyme immunoassay and results are expressed as percentage of maximal release for each stimuli. Values are means from four to six individual experiments, with standard errors represented by vertical bars. * Significant inhibition compared with maximal release for each stimuli $(P<0.05)$.

This augmented expression of COX-2 protein was reduced by treatment with ellagic acid: a $50 \%$ reduction in the LPS-induced expression of COX-2 protein was seen at $30 \mu \mathrm{M}$-ellagic acid. Regarding mPGEs-1 protein, this could be detected in control cells; however, the expression was increased about five-fold in response to LPS treatment (Fig. 2(c)). Ellagic acid suppressed the LPS-induced increase in expression of mPGEs- 1 and an $80 \%$ inhibition was seen at $30 \mu \mathrm{M}$-ellagic acid. $\mathrm{CPLA}_{2} \alpha$ protein was detected in control cells and the expression was further increased by treatment with LPS (Fig. 2(d)). Ellagic acid inhibited the LPS-induced increase in $\mathrm{CPLA}_{2} \alpha$ protein down to the level seen in control cells and this inhibition was seen already at $10 \mu$ M-ellagic acid.

Activity of prostaglandin-synthesising enzymes in subcellular fractions from control, lipopolysaccharide-and ellagic acid plus lipopolysaccharide-treated cells

In addition to the protein expression of COX, mPGEs- 1 and ${ }_{c P L A} \alpha$, the activity of these enzymes was determined using subcellular fractions from control, LPS- and ellagic acid plus LPS-treated cells. Supernatant fractions from $1700 \mathrm{~g}$ centrifugation of cell lysates were assayed for combined activity of COX and PGEs, measured as the conversion of exogenously added AA to $\mathrm{PGE}_{2}$. Lysates from LPS-treated cells resulted in a ten-fold increase in the combined activity of COX and PGEs compared with lysates from control cells and this increase in activity was inhibited by $80 \%$ in lysates from ellagic acid plus LPS-treated cells (Fig. 3(a)). mPGEs activity was determined in microsomal fractions by analysing the conversion of exogenous $\mathrm{PGH}_{2}$ to $\mathrm{PGE}_{2}$. As shown in Fig. 3(b), the mPGEs activity in microsomal fractions from
LPS-treated cells was increased by a factor of 3 as compared with that seen from control cells. The mPGEs activity in microsomal fractions from cells treated with $30 \mu \mathrm{M}$-ellagic acid plus LPS was reduced by $85 \%$ compared with that seen from LPS-treated cells. For measurements of $\mathrm{cPLA}_{2} \alpha$ activity, cytosolic fractions were analysed using sonicated vesicles of 1-stearoyl-2[ $\left.{ }^{14} \mathrm{C}\right]$ arachidonoyl-phosphatidylcholine as substrate. As shown in Fig. 3(c), LPS treatment of cells enhanced the $\mathrm{CPLA}_{2} \alpha$ activity by a factor of 1.3 compared with the activity seen in cytosolic fractions from control cells. Treatment of cells with $30 \mu \mathrm{M}$-ellagic acid resulted in inhibition of the LPS-induced increase in $\mathrm{CPLA}_{2} \alpha$ activity down to the activity seen in cytosolic fractions from control cells.

Effects of ellagic acid on the activity of cyclo-oxygenase, microsomal PGE synthase and cytosolic phospholipase $A_{2} \alpha$ in a cell-free assay

To investigate if ellagic acid has any direct effect on the activity of COX, mPGEs and $\mathrm{CPLA}_{2} \alpha$, subcellular fractions were pre-treated with ellagic acid before analysis of the activity of these enzymes. Addition of ellagic acid had no direct effect on the enzymic activity of mPGES and $\mathrm{cPLA}_{2} \alpha$ (Fig. 4). Somewhat surprisingly, addition of ellagic acid $(10-30 \mu \mathrm{M})$ resulted in a two-fold increase in the combined activity of COX and PGEs (see Discussion). Although subcellular fractions from LPS-treated cells were used in the set of experiments shown in Fig. 4, the same results were seen using subcellular fractions from control cells, that is, no effect on the activity of mPGEs and $\mathrm{cPLA}_{2} \alpha$ and a two-fold increase in the combined COX and PGEs activity (results not shown).

\section{Discussion}

We have investigated the effect of ellagic acid on $\mathrm{PGE}_{2}$ release in human monocytes as well as its effects on protein expression and enzymic activity of $\mathrm{cPLA}_{2} \alpha, \mathrm{COX}$ and mPGEs-1. The experimental set-up in the present study, treatment of monocytes with LPS for $20 \mathrm{~h}$, resulted in expression of COX-2 protein, an increase in the expression of mPGEs-1 and, also to some extent, an increase in the expression of $\mathrm{CPLA}_{2} \alpha$. We found that the $\mathrm{PGE}_{2}$ release induced by A23187, opsonised zymosan and PMA stimulation of LPSpre-treated monocytes was inhibited by ellagic acid in a concentration-dependent manner with an 80-90\% inhibition at $30 \mu \mathrm{M}$-ellagic acid. When comparing this with the effects of ellagic acid on the expression of involved enzymes, we found no effect of ellagic acid on the expression of COX-1 protein, suggesting that this isoform of COX does not, to any major extent, contribute to the $\mathrm{PGE}_{2}$ release seen under our conditions. In contrast, ellagic acid inhibited the LPS-induced expression of COX-2 protein, with a $50 \%$ inhibition at $30 \mu \mathrm{M}$-ellagic acid. mPGEs- 1 is considered to be an inducible enzyme ${ }^{(9,24)}$; however, we found a low but consistent expression in control monocytes. The existence of mPGEs-1 in control cultures has also been seen in other cell types such as fibroblasts ${ }^{(25)}$ and microglia cells ${ }^{(26)}$. The protein expression of mPGEs-1 was up-regulated in response to LPS treatment and this increase was reduced by ellagic acid, 
with an $80 \%$ inhibition at $30 \mu \mathrm{M}$-ellagic acid. We have not investigated the effect of ellagic acid on the expression of the two other isoforms of PGEs: cPGEs and mPGEs-2. However, based on other reports, these isoforms are less likely to be involved in the $\mathrm{PGE}_{2}$ release under the conditions

(a)
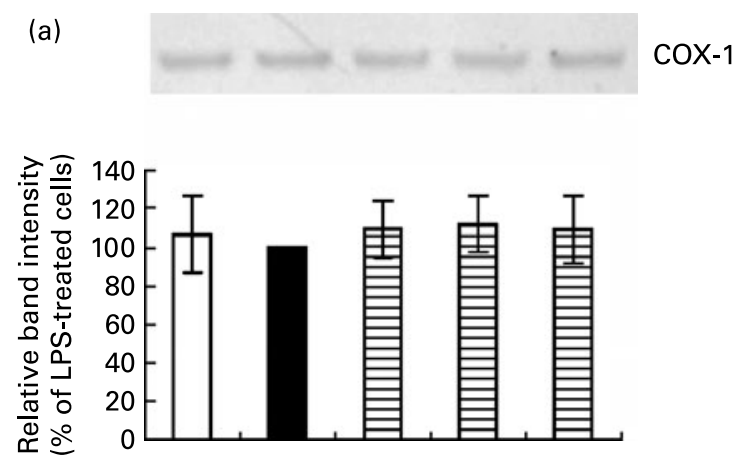

(b)
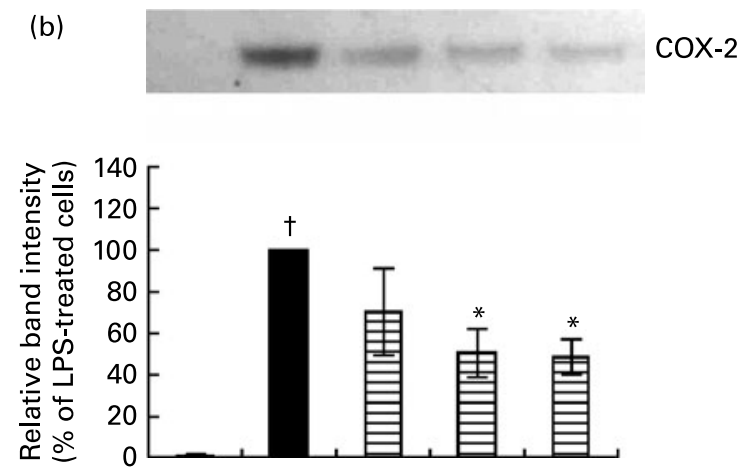

(c)

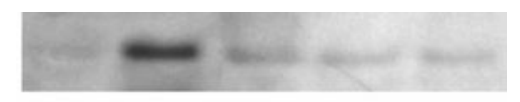

mPGEs-1

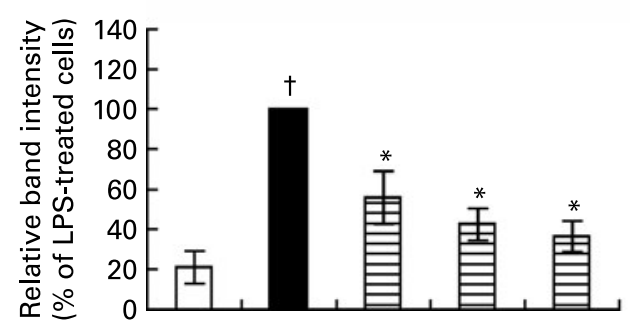

(d)
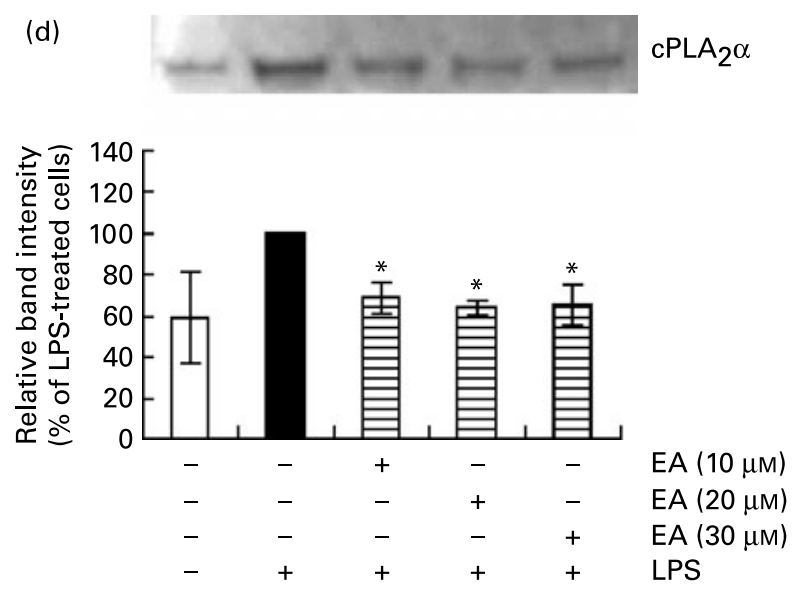

applied in the present study. First, the expression of cPGEs and mPGEs- 2 have been shown not to be affected by LPS treatment of microglia cells ${ }^{(26)}$ and liver macrophages ${ }^{(27)}$ or by IL-1 $\beta$ treatment of gastric fibroblasts ${ }^{(28)}$. Second, macrophages from mPGEs-1 knockout mice produced substantially reduced levels of $\mathrm{PGE}_{2}$ compared with macrophages from wild-type mice ${ }^{(29-31)}$. In addition to effects on COX-2 and mPGEs-1 protein, we also found ellagic acid to inhibit the LPS-induced increase in $\mathrm{CPLA}_{2} \alpha$ protein. Thus, ellagic acid reduced the LPS-induced increase in protein expression of all three enzymes involved in the synthesis of $\mathrm{PGE}_{2}$ and this was accompanied by a reduction in the activity of the enzymes when assaying subcellular fractions from cells treated with ellagic acid plus LPS compared with LPS alone.

Although ellagic acid reduced the LPS-induced increase in expression of all three enzymes, the present results support a role for COX-2 and mPGEs-1, but not $\mathrm{cPLA}_{2} \alpha$, to be rate limiting in the synthesis of $\mathrm{PGE}_{2}$ in monocytes. This is based on the observations that COX-2 and mPGEs- 1 protein expression showed a tendency to being concentrationdependently inhibited by ellagic acid in the range of $10-30 \mu \mathrm{M}$ and this was similar to the inhibition of the $\mathrm{PGE}_{2}$ release. In contrast, $\mathrm{cPLA}_{2} \alpha$ protein was maximally affected already at $10 \mu \mathrm{M}$-ellagic acid while $\mathrm{PGE}_{2}$ release continued to decline with 20 and $30 \mu \mathrm{M}$-ellagic acid.

In order to exclude a direct inhibitory effect of ellagic acid on the activity of COX, mPGEs and $\mathrm{cPLA}_{2} \alpha$, we also performed experiments where ellagic acid was added to subcellular fractions for measuring enzymic activity. mPGEs and $\mathrm{CPLA}_{2} \alpha$ activity was not affected by the addition of ellagic acid while it increased the combined activity of COX and PGEs. We have no explanation for this increase in activity. However, due to the fact that ellagic acid had no direct effect on the mPGEs activity and that cPGEs is less likely to be involved, based on its low catalytic efficiency compared with mPGEs- $1^{(32)}$, we suggest that the enhancing effect of ellagic acid is due to an effect on the COX enzymes. Phenols in the low millimolar range have been shown to enhance COX activity and this effect has been attributed to stimulation of the peroxidase activity of COX as well as preventing the enzyme from self-catalysed inactivation ${ }^{(33)}$. Ellagic acid could potentially work in a similar way as phenols, in stimulating COX activity, when added directly to subcellular fractions for activity measurements.

The mechanisms by which ellagic acid inhibits the LPSinduced expression of COX-2, mPGEs-1 and $\mathrm{CPLA}_{2} \alpha$ is unknown; however, it most likely involves effects on protein kinases and/or transcription factors. Ellagic acid has been

Fig. 2. Effect of ellagic acid (EA) on protein expression of cyclo-oxygenase (COX)-1, COX-2, microsomal PGE synthase-1 (mPGEs-1) and cytosolic phospholipase $\mathrm{A}_{2} \alpha\left(\mathrm{CPLA}_{2} \alpha\right)$ in monocytes. Protein expression of COX-1 (a), COX-2 (b), mPGEs-1 (c) and cPLA ${ }_{2} \alpha$ (d) in control cells and cells treated with lipopolysaccharide (LPS; $1 \mu \mathrm{g} / \mathrm{ml}$ ) for $20 \mathrm{~h}$ in the prescence or abscence of 10,20 or $30 \mu \mathrm{M}-\mathrm{EA}$ was analysed by immunoblotting. The relative band intensities were determined with Image Quant TL and intensity values of COX-2, mPGEs- 1 and $\mathrm{cPLA}_{2} \alpha$ were normalised to the corresponding value of COX-1 and are expressed as percentage of the response of LPS alone. Values are means from five individual experiments, with standard errors represented by vertical bars. * Significant inhibition $v$. LPS-treated cells $(P<0.05)$. † Significant induction $v$. control cells $(P<0.05)$. 
shown to inhibit several different protein kinases. Among these, extracellular signal-regulated protein kinase ${ }^{(17,18)}$, p38 $8^{(18)}$ and c-Jun N-terminal kinase ${ }^{(18)}$ are of special interest since they have been suggested to participate in the regulation of the expression of both COX-2 $2^{(34-36)}$ and mPGEs- $1^{(37)}$. Regarding transcription factors, ellagic acid has been shown to inhibit activation of $\mathrm{NF \kappa B}$ in response to LPS stimulation of human intestinal $\mathrm{CaCo} 2$ cells ${ }^{(2)}$, IL-1ß stimulation of endothelial cells ${ }^{(16)}$ and human pancreatic adenocarcinoma cells $^{(19)}$. This is of interest since the promoter region of both $\mathrm{CPLA}_{2} \mathrm{\alpha}$ and $\mathrm{COX}-2$ have binding sites for $\mathrm{NF}_{\kappa} \mathrm{B}^{(38)}$. NFKB activation has been shown to mediate LPS-induced expression of COX-2 in macrophages ${ }^{(39)}$ and also $\mathrm{cPLA}_{2} \alpha$ expression has been suggested to be mediated via $\mathrm{NFKB}^{(40,41)}$. IL-1 $\beta$-induced expression of mPGEs-1 in chondrocytes has also been suggested to be regulated via $\mathrm{NF}_{\kappa} \mathrm{B}^{(42)}$. However, no binding

(a)

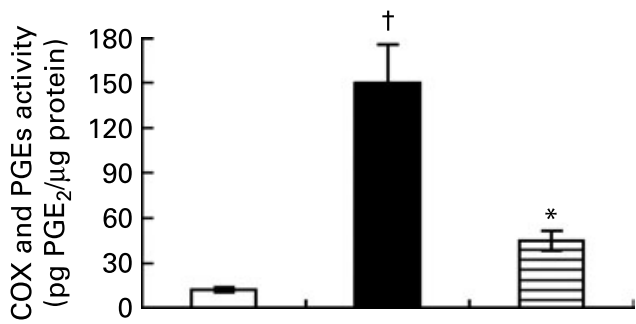

(b)

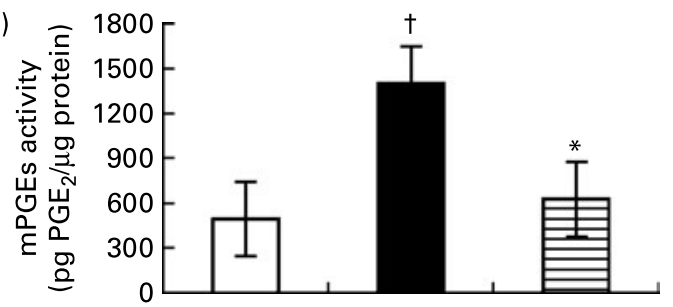

(c)

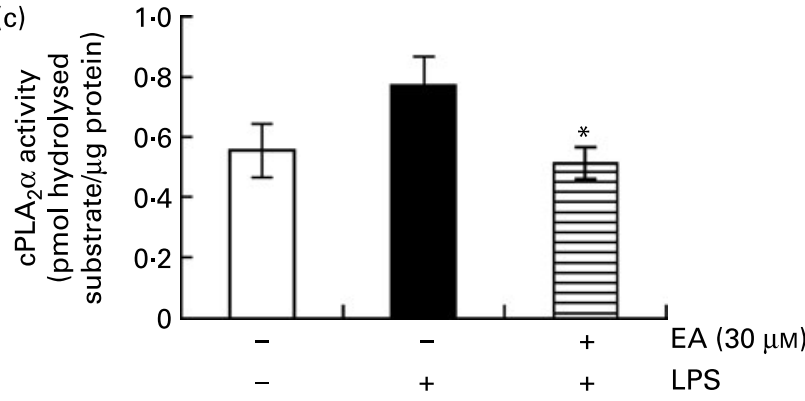

Fig. 3. Activity of cyclo-oxygenase (COX) and PGE synthase (PGEs), microsomal PGEs (mPGEs) and cytosolic phospholipase $A_{2} \alpha\left(\mathrm{CPLA}_{2} \alpha\right)$ in subcelIular fractions from control, lipopolysaccharide (LPS)- and LPS plus ellagic acid (EA)-treated monocytes. Cells were left untreated (control), treated with LPS $(1 \mu \mathrm{g} / \mathrm{ml})$ alone for $20 \mathrm{~h}$ or treated with $30 \mu \mathrm{M}$-EA for $21 \mathrm{~h}$ in combination with LPS. Subcellular fractions were prepared as described in Materials and methods and assayed for combined COX and PGEs activity in $1700 \mathrm{~g}$ supernatant fractions using arachidonic acid (AA) as the substrate (a), mPGEs activity in the microsomal fraction using $\mathrm{PGH}_{2}$ as the substrate (b) and $\mathrm{CPLA}_{2} \alpha$ activity in cytosolic fractions using sonicated vesicles of 1 -stearoyl$2\left[{ }^{14} \mathrm{C}\right]$ arachidonoyl-phosphatidylcholine $\left(\left[{ }^{14} \mathrm{C}\right] \mathrm{AAPC}\right)$ as the substrate (c). Results are presented as $\mathrm{pg} \mathrm{PGE}_{2} / \mu \mathrm{g}$ protein for COX and PGEs activity and as pmol hydrolysed $\mathrm{AA} / \mu \mathrm{g}$ protein for $\mathrm{CPLA}_{2} \alpha$ activity. Values are means from three individual experiments in (a) and from four individual experiments in (b) and (c), with standard errors represented by vertical bars. * Significant inhibition $v$. LPS-treated cells $(P<0.05)$. † Significant induction $v$. control cells $(P<0.05)$ site for $\mathrm{NF \kappa B}$ has been found in the promoter region of mPGEs-1 and it has therefore been suggested that the effect of $\mathrm{NF \kappa B}$ is mediated via activation of the transcription factor early growth response- $1^{(42)}$, which has been shown to induce expression of mPGEs- $1^{(43)}$.

There are relatively few reports regarding the absorption and metabolism of ellagic acid in response to dietary intake of fruits and juices containing ellagic acid in human subjects. Seeram et al. ${ }^{(44)}$ have reported submicromolar levels of ellagic acid to be present in plasma after consumption of $180 \mathrm{ml}$ pomegranate juice (containing $12 \mathrm{mg}$ free ellagic acid). This is a lower concentration of ellagic acid than the $5-30 \mu \mathrm{M}$ used in the present study on monocytes and also lower than that used in several other cellular studies ${ }^{(16,18-20,45)}$. However, no studies on the uptake have been performed after intake of higher doses of pomegranate juice or pure ellagic acid, which potentially could result in higher levels in plasma. Of relevance for potential effects of ellagic acid on inflammatory reactions, consumption of pomegranate juice has been shown to reduce LDL oxidation ${ }^{(46)}$, systemic blood pressure $^{(47)}$ and stress-induced ischaemia ${ }^{(48)}$. All of these inflammatory responses could potentially involve $\mathrm{PGE}_{2}$.

In conclusion, we have shown that ellagic acid inhibits $\mathrm{PGE}_{2}$ release in human monocytes and that this inhibition is mediated by an inhibition of the LPS-induced expression of cPLA $_{2} \alpha$, COX- 2 and mPGEs- 1 proteins and not by a direct effect on the activity of the enzymes. Adams et al. ${ }^{(45)}$ have previously shown that pomegranate juice inhibited $\mathrm{TNF} \alpha$ induced expression of COX-2 in HT 29 colon cancer cells. Pomegranate juice contains ellagic acid but also other bioactive polyphenols, such as flavonoids, that may have contributed to the inhibition of COX-2 expression in the

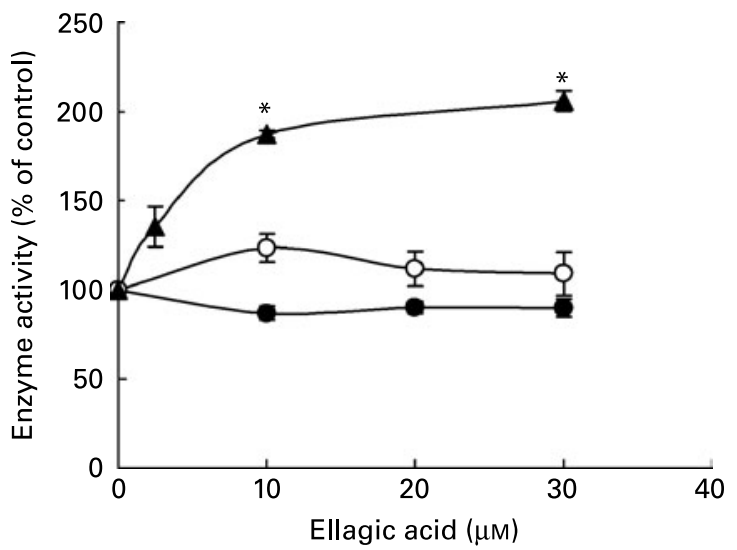

Fig. 4. Effects of ellagic acid on the enzymic activity of cyclo-oxygenase (COX) and PGE synthase (PGEs), microsomal PGEs (mPGEs) and cytosolic phospholipase $A_{2} \alpha\left(c P L A_{2} \alpha\right)$. Subcellular fractions from cells treated with lipopolysaccharide were analysed with or without the addition of ellagic acid $(2.5-30 \mu \mathrm{M})$ in the reaction mixture. Subcellular fractions (prepared as described in Materials and methods) were assayed for combined COX and PGEs activity $(\mathbf{\Lambda})$ in $1700 \mathrm{~g}$ supernatant fractions using arachidonic acid as the substrate, mPGEs activity $(O)$ in the microsomal fraction using $\mathrm{PGH}_{2}$ as the substrate and $\mathrm{CPLA}_{2} \alpha$ activity $(\bullet)$ in the cytosolic fraction using sonicated vesicles of 1-stearoyl-2[ $\left[{ }^{14} \mathrm{C}\right]$ arachidonoyl-phosphatidylcholine $\left(\left[{ }^{14} \mathrm{C}\right] \mathrm{AAPC}\right)$ as the substrate. Results are presented as percentage of control (no addition of ellagic acid). Values are means from three (combined COX and PGEs activity) or four (mPGEs and $\mathrm{cPLA}_{2} \alpha$ activity) individual experiments, with standard errors represented by vertical bars. * Significant increase in activity compared with control $(P<0.05)$. 
colon cancer cells. However, the present study is to our knowledge the first report to show effects of ellagic acid on the expression of enzymes involved in the formation of $\mathrm{PGE}_{2}$. Future studies are required to elucidate the mechanisms, such as effects on protein kinases and transcription factors, by which ellagic acid inhibits the LPS-induced expression of prostaglandin-synthesising enzymes.

\section{Acknowledgements}

The present study was financially supported by The County Council of Värmland.

E. N. and C. F. were initiators of the study. S. K. and J. W. designed the study and $\mathrm{S}$. K. performed all the experiments. S. K. and J. W. wrote the manuscript.

We thank Cecilia Roos for critical reading of the manuscript.

There are no conflicts of interest.

\section{References}

1. Funk CD (2001) Prostaglandins and leukotrienes: advances in eicosanoid biology. Science 294, 1871-1875.

2. Murakami M, Shimbara S, Kambe T, et al. (1998) The functions of five distinct mammalian phospholipase $\mathrm{A}_{2} \mathrm{~S}$ in regulating arachidonic acid release. Type IIa and type $\mathrm{V}$ secretory phospholipase $\mathrm{A}_{2} \mathrm{~S}$ are functionally redundant and act in concert with cytosolic phospholipase $\mathrm{A}_{2}$. J Biol Chem 273, 14411-14423.

3. Schaloske RH \& Dennis EA (2006) The phospholipase $\mathrm{A}_{2}$ superfamily and its group numbering system. Biochim Biophys Acta 1761, 1246-1259.

4. Leslie CC (2004) Regulation of the specific release of arachidonic acid by cytosolic phospholipase $\mathrm{A}_{2}$. Prostaglandins Leukot Essent Fatty Acids 70, 373-376.

5. Shimizu T, Ohto T \& Kita Y (2006) Cytosolic phospholipase $\mathrm{A}_{2}$ : biochemical properties and physiological roles. IUBMB Life 58, 328-333.

6. Nichols FC, Garrison SW \& Davis HW (1988) Prostaglandin $E_{2}$ and thromboxane $\mathrm{B}_{2}$ release from human monocytes treated with bacterial lipopolysaccharide. J Leukoc Biol 44, 376-384.

7. Park JY, Pillinger MH \& Abramson SB (2006) Prostaglandin $\mathrm{E}_{2}$ synthesis and secretion: the role of $\mathrm{PGE}_{2}$ synthases. Clin Immunol 119, 229-240.

8. Murakami M \& Kudo I (2004) Recent advances in molecular biology and physiology of the prostaglandin $\mathrm{E}_{2}$-biosynthetic pathway. Prog Lipid Res 43, 3-35.

9. Murakami M, Naraba H, Tanioka T, et al. (2000) Regulation of prostaglandin $\mathrm{E}_{2}$ biosynthesis by inducible membraneassociated prostaglandin $E_{2}$ synthase that acts in concert with cyclooxygenase-2. J Biol Chem 275, 32783-32792.

10. Losso JN, Bansode RR, Trappey AII, et al. (2004) In vitro antiproliferative activities of ellagic acid. J Nutr Biochem 15, 672-678.

11. Fjaeraa C \& Nånberg E (2009) Effect of ellagic acid on proliferation, cell adhesion and apoptosis in SH-SY5Y human neuroblastoma cells. Biomed Pharmacother 63, 254-261.

12. Mertens-Talcott SU, Talcott ST \& Percival SS (2003) Low concentrations of quercetin and ellagic acid synergistically influence proliferation, cytotoxicity and apoptosis in MOLT-4 human leukemia cells. J Nutr 133, 2669-2674.

13. Ross HA, McDougall GJ \& Stewart D (2007) Antiproliferative activity is predominantly associated with ellagitannins in raspberry extracts. Phytochemistry 68, 218-228.

14. Seeram NP, Adams LS, Zhang Y, et al. (2006) Blackberry, black raspberry, blueberry, cranberry, red raspberry, and strawberry extracts inhibit growth and stimulate apoptosis of human cancer cells in vitro. J Agric Food Chem 54, 9329-9339.

15. Papoutsi Z, Kassi E, Chinou I, et al. (2008) Walnut extract (Juglans regia L.) and its component ellagic acid exhibit antiinflammatory activity in human aorta endothelial cells and osteoblastic activity in the cell line KS483. Br J Nutr 99, $715-722$.

16. Yu YM, Wang ZH, Liu CH, et al. (2007) Ellagic acid inhibits IL-1 $\beta$-induced cell adhesion molecule expression in human umbilical vein endothelial cells. Br J Nutr 97, 692-698.

17. Chang WC, Yu YM, Chiang SY, et al. (2008) Ellagic acid suppresses oxidised low-density lipoprotein-induced aortic smooth muscle cell proliferation: studies on the activation of extracellular signal-regulated kinase $1 / 2$ and proliferating cell nuclear antigen expression. Br J Nutr 99, 709-714.

18. Masamune A, Satoh M, Kikuta K, et al. (2005) Ellagic acid blocks activation of pancreatic stellate cells. Biochem Pharmacol 70, 869-878.

19. Edderkaoui M, Odinokova I, Ohno I, et al. (2008) Ellagic acid induces apoptosis through inhibition of nuclear factor $\kappa \mathrm{B}$ in pancreatic cancer cells. World J Gastroenterol 14, 3672-3680.

20. Romier B, Van De Walle J, During A, et al. (2008) Modulation of signalling nuclear factor- $\kappa \mathrm{B}$ activation pathway by polyphenols in human intestinal Caco-2 cells. Br J Nutr 100, 542-551.

21. Laemmli UK (1970) Cleavage of structural proteins during the assembly of the head of bacteriophage T4. Nature 227, 680-685.

22. Bradford MM (1976) A rapid and sensitive method for the quantitation of microgram quantities of protein utilizing the principle of protein-dye binding. Anal Biochem 72, 248-254.

23. Seno K, Okuno T, Nishi K, et al. (2001) Pyrrolidine inhibitors of human phospholipase $\mathrm{A}_{2}$. Part 2: Synthesis of a potent and crystallized 4-triphenylmethylthio derivative pyrrophenone. Bioorg Med Chem Lett 11, 587-590.

24. Jakobsson PJ, Thoren S, Morgenstern R, et al. (1999) Identification of human prostaglandin E synthase: a microsomal, glutathione-dependent, inducible enzyme, constituting a potential novel drug target. Proc Natl Acad Sci U S A 96, 7220-7225.

25. Shinji Y, Tsukui T, Tatsuguchi A, et al. (2005) Induced microsomal PGE synthase-1 is involved in cyclooxygenase-2dependent $\mathrm{PGE}_{2}$ production in gastric fibroblasts. Am J Physiol Gastrointest Liver Physiol 288, G308-G315.

26. Ikeda-Matsuo Y, Ikegaya Y, Matsuki N, et al. (2005) Microgliaspecific expression of microsomal prostaglandin $\mathrm{E}_{2}$ synthase-1 contributes to lipopolysaccharide-induced prostaglandin $\mathrm{E}_{2}$ production. J Neurochem 94, 1546-1558.

27. Bezugla Y, Kolada A, Kamionka S, et al. (2006) COX-1 and COX-2 contribute differentially to the LPS-induced release of $\mathrm{PGE}_{2}$ and $\mathrm{TxA}_{2}$ in liver macrophages. Prostaglandins Other Lipid Mediat 79, 93-100.

28. Gudis K, Tatsuguchi A, Wada K, et al. (2005) Microsomal prostaglandin E synthase (mPGES)-1, mPGES-2 and cytosolic PGES expression in human gastritis and gastric ulcer tissue. Lab Invest 85, 225-236.

29. Boulet L, Ouellet M, Bateman KP, et al. (2004) Deletion of microsomal prostaglandin $\mathrm{E}_{2}\left(\mathrm{PGE}_{2}\right)$ synthase-1 reduces inducible and basal $\mathrm{PGE}_{2}$ production and alters the gastric prostanoid profile. J Biol Chem 279, 23229-23237.

30. Kamei D, Yamakawa K, Takegoshi Y, et al. (2004) Reduced pain hypersensitivity and inflammation in mice lacking microsomal prostaglandin E synthase-1. J Biol Chem 279, 33684-33695.

31. Trebino CE, Eskra JD, Wachtmann TS, et al. (2005) Redirection of eicosanoid metabolism in mPGES-1-deficient macrophages. J Biol Chem 280, 16579-16585.

32. Thorén S, Weinander R, Saha S, et al. (2003) Human microsomal prostaglandin E synthase-1: purification, functional 
characterization, and projection structure determination. $J$ Biol Chem 278, 22199-22209.

33. Hsuanyu Y \& Dunford HB (1992) Prostaglandin H synthase kinetics. The effect of substituted phenols on cyclooxygenase activity and the substituent effect on phenolic peroxidatic activity. J Biol Chem 267, 17649-17657.

34. Arbabi S, Rosengart MR, Garcia I, et al. (2000) Hypertonic saline solution induces prostacyclin production by increasing cyclooxygenase-2 expression. Surgery 128, 198-205.

35. Hwang D, Jang BC, Yu G, et al. (1997) Expression of mitogeninducible cyclooxygenase induced by lipopolysaccharide: mediation through both mitogen-activated protein kinase and NF-кB signaling pathways in macrophages. Biochem Pharmacol 54, 87-96.

36. Scherle PA, Ma W, Lim H, et al. (2000) Regulation of cyclooxygenase-2 induction in the mouse uterus during decidualization. An event of early pregnancy. J Biol Chem 275, 37086-37092.

37. Masuko-Hongo K, Berenbaum F, Humbert L, et al. (2004) Up-regulation of microsomal prostaglandin $\mathrm{E}$ synthase 1 in osteoarthritic human cartilage: critical roles of the ERK-1/2 and p38 signaling pathways. Arthritis Rheum 50, 2829-2838.

38. Hughes-Fulford M, Tjandrawinata RR, Li CF, et al. (2005) Arachidonic acid, an omega- 6 fatty acid, induces cytoplasmic phospholipase $\mathrm{A}_{2}$ in prostate carcinoma cells. Carcinogenesis 26, $1520-1526$.

39. D'Acquisto F, Iuvone T, Rombola L, et al. (1997) Involvement of NF- $\kappa \mathrm{B}$ in the regulation of cyclooxygenase-2 protein expression in LPS-stimulated J774 macrophages. FEBS Lett 418, 175-178.

40. Dieter P, Hempel U, Kamionka S, et al. (1999) Prostaglandin $E_{2}$ affects differently the release of inflammatory mediators from resident macrophages by LPS and muramyl tripeptides. Mediators Inflamm 8, 295-303.
41. Morri H, Ozaki M \& Watanabe Y (1994) 5'-Flanking region surrounding a human cytosolic phospholipase $\mathrm{A}_{2}$ gene. Biochem Biophys Res Commun 205, 6-11.

42. Bianchi A, Moulin D, Sebillaud S, et al. (2005) Contrasting effects of peroxisome-proliferator-activated receptor (PPAR) $\gamma$ agonists on membrane-associated prostaglandin $\mathrm{E}_{2}$ synthase-1 in IL-1 $\beta$-stimulated rat chondrocytes: evidence for PPAR $\gamma$ independent inhibition by 15 -deoxy- $\Delta_{12,14}$ prostaglandin $\mathrm{J}_{2}$. Arthritis Res Ther 7, R1325-R1337.

43. Naraba H, Yokoyama C, Tago N, et al. (2002) Transcriptional regulation of the membrane-associated prostaglandin $E_{2}$ synthase gene. Essential role of the transcription factor Egr-1. J Biol Chem 277, 28601-28608.

44. Seeram NP, Henning SM, Zhang Y, et al. (2006) Pomegranate juice ellagitannin metabolites are present in human plasma and some persist in urine for up to 48 hours. J Nutr 136, $2481-2485$.

45. Adams LS, Seeram NP, Aggarwal BB, et al. (2006) Pomegranate juice, total pomegranate ellagitannins, and punicalagin suppress inflammatory cell signaling in colon cancer cells. J Agric Food Chem 54, 980-985.

46. Aviram M, Dornfeld L, Rosenblat M, et al. (2000) Pomegranate juice consumption reduces oxidative stress, atherogenic modifications to LDL, and platelet aggregation: studies in humans and in atherosclerotic apolipoprotein E-deficient mice. Am J Clin Nutr 71, 1062-1076.

47. Aviram M \& Dornfeld L (2001) Pomegranate juice consumption inhibits serum angiotensin converting enzyme activity and reduces systolic blood pressure. Atherosclerosis 158, 195-198.

48. Sumner MD, Elliott-Eller M, Weidner G, et al. (2005) Effects of pomegranate juice consumption on myocardial perfusion in patients with coronary heart disease. Am J Cardiol 96, 810-814. 